\title{
Selection of Dominant and Co-dominant Markers for Red Wood (Pterocarpus indicus Willd) Polymorphism from Five Provenances in East Nusa Tenggara
}

\author{
Siti Halimah Larekeng \\ Biotechnology and Tree Breeding Laboratory, Department of Forestry, Faculty of Forestry, \\ Universitas Hasanuddin, Indonesia. 90245 \\ \{sitih5h.82@gmail.com\}
}

\begin{abstract}
Information about the genetic diversity of Red wood is needed to improve the quality and quantity of the plant. This information can be provided by analyzing plant DNA using molecular markers which are polymorphic and generate clear and thick bands. The objective of the study was to obtain primers that could generate clear and polymorphically bands from Red wood DNA. The evaluated Red wood was from Alor, Sika, Lembata, Rote, and Timur Tengah Selatan (TTS) provenances. As many as 54 primers screened to polymorphism assay. Those primers consisted of RAPD, SSR, and chloroplast.The SSR primers were developed from Pterocarpus indicus (six primers) and Prosopis alba (12 primers). Chloroplast primers were divided into two types, four Rubisco Large Sub-unit genes (rbcL) and 12 MaturaseK genes (matK). SSR primers of $\mathrm{P}$. alba were not able to amplify Red wood DNA, whereas those of P. indicus could amplify the DNA. Three of each chloroplast primers successfully amplified the DNA, yet, each primer could only amplify one to four of 12 evaluated samples. rbcL 2 generated the highest number of sample, and samples from Lembata were amplified the most. Moreover, 16 RAPD primers were able to generate DNA.
\end{abstract}

Keywords: Genetic marker, matK, RAPD, rbcL, SSR, Red wood.

\section{Introduction}

A genetic marker is a tool to analyze the genetic diversity of an individual including trees. A molecular marker is one of the genetic markers that can distinguish individuals by carrying out an analysis at the level of Deoxyribose Nucleic Acid (DNA). This marker is more accurate than other genetic markers as it is not influenced by the environment.

Molecular markers can be developed from nucleus DNA or cytoplasmic DNA, such as chloroplasts DNA. The developed markers are Random Amplified Polymorphic DNA (RAPD), Simple Sequence Repeat (SSR), Amplified Fragment Length Polymorphic (AFLP), Single Nucleotide Polymorphism (SNP), and Inter-Simple Sequence Repeat (ISSR). Meanwhile, molecular markers developed from chloroplast DNA are matK, rbcL, SSRcp and others. These markers are primers used for DNA amplification in genetic analysis.

Primer is a nucleic acid chain that functions as a starting point for synthesizing DNA, which is needed for DNA replication because the enzymes that catalyze this process are DNA polymerase. Primer screening aims to obtain a high polymorphism level, and thus the used primers were selected from several plant species sharing the same family with the studied 
species. This selection is done to find random primers that produce bands, both clearness of the band and number of the locus [1].

RAPD marker is dominant, and consequently, the produced DNA fragments cannot distinguish between homozygous (AA) and heterozygotes (Aa) individuals, whereas those without bands are recessive (aa) genotypes [3]. The utilization of co-dominant marker, for instance SSR, is needed in analyzing the genetic diversity because it is able to distinguish homozygous and heterozygous individuals. SSR has a simple sequence consisting one to six bases that are repeated and often found in plant genomes [4]. The variation in the number of repetitions of microsatellite sequences causes it has high polymorphism level and suitable for utilizing in genetic diversity of a population and parental analysis studies [5]. Molecular analysis can also be performed using the chloroplast genome. This analysis is able to identify genetic diversity and phylogenetic between species. rbcL and matK chloroplast genome markers are recommended primers for analysis in plants [6].

The distribution of Red wood in Indonesia is quite extensive, especially in eastern Indonesia; Sulawesi, Maluku, West Nusa Tenggara, East Nusa Tenggara, and Papua. Even though having widespread distribution, it has experienced a decline in population and genetic diversity hence it has been categorized as Vulnerable species in the International Union for Conservation of Nature (IUCN) Red List of Threatened Species due to high exploitation [7]. Efforts to maintain the existence of Red wood need to be done for the preservation of this species in the future in order to improve the plant characters and plant breeding.

The previous studies on primer screening have been done on Vitex coffassus [1], Elmerillia tsiampacca [8], Swietenia mahogany [9], Swietenia macrophylla [10]. Information about the suitable primers that can amplify the Red wood DNA is still limited. Therefore, study on primer screening with several primer types needs to be done. The objective of the study was to obtain primers that could amplify clear and polymorphic bands from Red wood DNA.

\section{Material and Methods}

This study was conducted in September 2018 up to March 2019 at Biotechnology and Tree Breeding Laboratory, Faculty of Forestry, Hasanuddin University, Makassar, Indonesia. Leaves of Red wood were collected from genetic resources area of Watershed Management Center of East Nusa Tenggara (BPDAS Nusa Tenggara Timur) located in Silu village, Kupang, East Nusa Tenggara, Indonesia. The seedling collected at the study site were from Alor, Rote, Sika, Lembata, dan Timur Tengah Selatan (TTS) provenances. Twelve DNA samples of Red wood were selected for primer screening; three samples from Rote and Lembata, and two samples from Alor, Sika, and TTS, respectively. Leaves were weighed as much as $100 \mathrm{mg}$ and then grounded for the DNA extraction process. The DNA extraction procedure was done using DNA Geneaid extraction kit protocol. The extracted DNA was mixed with RNase and stored in $-20^{\circ} \mathrm{C}$ freezer for 24 hours. After 24 hours, the DNA working solution was prepared by diluting $1 \mu \mathrm{L}$ DNA master with $9 \mu \mathrm{L}$ ddH $\mathrm{H}_{2} \mathrm{O}$.

Primer screening used RAPD, SSR, and Chloroplast primers. Nine RAPD primers, six SSR primers from Pterocarpus indicus [6], four rbcL primers, and twelve matK primers were screened in this study (Table 1).

DNAs were amplified using PCR Sensoquest Thermal Cycler with one PCR reaction consisted of $2 \mu \mathrm{L}$ of DNA template; $0,625 \mu \mathrm{L}$ of Hotstar PCR mix; and $3 \mu \mathrm{L}$ of $\mathrm{ddH}_{2} \mathrm{O}$. One PCR reaction for RAPD marker contained $1,25 \mu \mathrm{L}$ of RAPD primer, while that of SSR and chloroplast markers contained $1,25 \mu \mathrm{L}$ primers $(0.625 \mu \mathrm{L}$ of forward and $0.625 \mu \mathrm{L}$ of reverse). The amplification was performed using the following steps: one cycle of preheat at $95^{\circ} \mathrm{C}$ for 5 minutes, 35 cycles of denaturation at $94^{\circ} \mathrm{C}$ for 60 seconds, primer annealing at annealing 
temperature for each primer for one minute, elongation at $72^{\circ} \mathrm{C}$ for 60 seconds, and final elongation at $72^{\circ} \mathrm{C}$ at 10 minutes. The precise annealing temperature for each primer was determined by doing a temperature gradient at $\pm 5^{\circ} \mathrm{C}$ of each primer temperature.

SSR amplification products were separated on 3\% of SFR agarose with 1x TAE buffer at $100 \mathrm{~V}$ for 90 minutes. Meanwhile, that of RAPD, RbcL, and MatK were separated on $2 \%$ of agarose with $1 \mathrm{x}$ TAE buffer at $100 \mathrm{~V}$ for 60 minutes. The products were then visualized over UV light and documented using a Gel Doc system.

Table 1. Primer name, sequence, and primer melting temperature

\begin{tabular}{|c|c|c|c|}
\hline No & Locus Name & Primer Sequence & $\begin{array}{c}\text { Melting } \\
\text { Temperature } \\
\left({ }^{\circ} \mathrm{C}\right)\end{array}$ \\
\hline & $\begin{array}{l}\text { SSR primers } \\
\text { of } P \text {. indicus }\end{array}$ & & \\
\hline 1 & $\begin{array}{l}\text { Pin2_36/GU9 } \\
03082\end{array}$ & $\begin{array}{l}\text { F: TCA AAA TTA GAA TGA AGG TGA G } \\
\text { R: GCAATAAGAGAGAATGAAGAAA }\end{array}$ & 51.2 \\
\hline 2 & $\begin{array}{l}\text { Pin2_29/GU9 } \\
03081\end{array}$ & $\begin{array}{l}\text { F: TCGTTTGGAAGTGTTTCCCATT } \\
\text { R: TACCACCTTGCCCGAGTTTATG }\end{array}$ & 54,1 \\
\hline 3 & $\begin{array}{l}\text { Pin2_04/GU9 } \\
03076\end{array}$ & $\begin{array}{l}\text { F: ATTGTCAGTTGATGTATCTTGC } \\
\text { R: TTTAATCAGCTTGTTTCCTATG }\end{array}$ & 49,9 \\
\hline 4 & $\begin{array}{l}\text { Pin1_23/GU9 } \\
03073\end{array}$ & $\begin{array}{l}\text { F: ATTCCTTGGATAGGCTGACAAT } \\
\text { R: CTGAAAGCACGAGAGCATTTTT }\end{array}$ & 56,1 \\
\hline 5 & $\begin{array}{l}\text { Pin1_04/GU9 } \\
03071\end{array}$ & $\begin{array}{l}\text { F: CTC GTA AGC CCA AGT CAA CAT A } \\
\text { R: AAT CAG AAA CCT AAA ACG GAA C }\end{array}$ & 52,9 \\
\hline 6 & $\begin{array}{l}\text { Pin1_01/GU9 } \\
03070\end{array}$ & $\begin{array}{l}\text { F: CTAACCTGAATACCAAGAAAACTCC } \\
\text { R: TCTCAAGAATAAAAAGATGTGC }\end{array}$ & 48,4 \\
\hline 7 & $\begin{array}{l}\text { Pin2_39/GU9 } \\
03083\end{array}$ & $\begin{array}{l}\text { F: GCAACACCTCCAACACCAAAAA } \\
\text { R: CTCTAATCССТСССТCGCCAAA }\end{array}$ & 57,6 \\
\hline & $\begin{array}{l}\text { SSR Primers } \\
\text { of Prosopis } \\
\text { alba }\end{array}$ & & \\
\hline 1 & GL3 & $\begin{array}{l}\text { F: CAC CGA TCTCACAAAGCTGC } \\
\text { R: AATGGATCTGGTGTTGTCGC }\end{array}$ & 56 \\
\hline 2 & JX136853 & $\begin{array}{l}\text { F: CTGGTTGCTGTGATTGGAGG } \\
\text { R: CTCCAGGGATCACAAGACAAAC }\end{array}$ & 55,8 \\
\hline 3 & $\begin{array}{l}\text { GL6 } \\
\text { JX136854 }\end{array}$ & $\begin{array}{l}\text { F: CAGGTGGGCATGAAGTTTCC } \\
\text { R: CCAAGAACAACCTGCCGAAG }\end{array}$ & 56,3 \\
\hline 4 & GL8 & $\begin{array}{l}\text { F: ACTCTGCGGGTTAGGTAAGC } \\
\text { R: ACCTGGAGCTGACATGGATC }\end{array}$ & 56,7 \\
\hline 5 & JX136855 & $\begin{array}{l}\text { F: GAGTGAAGGTCGGGAAGAGG } \\
\text { R: CCATTGGACCAAGGCAGAAC }\end{array}$ & 56,7 \\
\hline 6 & $\begin{array}{l}\text { GL9 } \\
\text { JX136856 }\end{array}$ & $\begin{array}{l}\text { F: GTGTTATGGTCCCAACAGCC } \\
\text { R: TGAAGAGGGAGGAATCGCAG }\end{array}$ & 56,4 \\
\hline 7 & GL12 & $\begin{array}{l}\text { F: GTTGGATTTCACGGAAGGGC } \\
\text { R: TCAGCTAAGTGGCCATACGG }\end{array}$ & 56,8 \\
\hline 8 & JX136857 & $\begin{array}{l}\text { F: GAGAATCTGGAGCAGCAACG } \\
\text { R: AAGGTAGCGTCCCAGGTATG }\end{array}$ & 56,2 \\
\hline
\end{tabular}




\begin{tabular}{|c|c|c|c|}
\hline \multirow[t]{2}{*}{9} & GL15 & F: ATCTCCGTCACAACTTGCAC & 56,1 \\
\hline & JX136858 & R: ACCCTCACTCCCGAATGATG & \\
\hline \multirow[t]{2}{*}{10} & & F: GTCTTCTCTCCCGTGGATCC & 56,4 \\
\hline & GL16 & R: TGAGGCAAAGGAAGAGCAAC & \\
\hline \multirow[t]{2}{*}{11} & JX136859 & F: CCTTAATCTCCCTCTCGGCC & 56,3 \\
\hline & & R: AACCAGGCTCTGCAGAAATG & \\
\hline \multirow[t]{11}{*}{12} & GL18 & F: CGAATGTGGATCTTCTGCGG & 55,8 \\
\hline & JX136860 & R: TTAAGCGGCCCAAGTTTCTC & \\
\hline & GL21 & & \\
\hline & JX136861 & & \\
\hline & GL23 & & \\
\hline & JX136862 & & \\
\hline & GL24 & & \\
\hline & JX136863 & & \\
\hline & GL26 & & \\
\hline & JX136864 & & \\
\hline & RAPD Primers & & \\
\hline 1 & OPQ-07 & CCCCGATGGT & 38,5 \\
\hline 2 & OPAC-12 & GGCGAGTGTG & 38,1 \\
\hline 3 & OPAE-11 & AAGACCGGGA & 35,5 \\
\hline 4 & OPAA-20 & TTG CCT TCG G & 35,6 \\
\hline 5 & OPA 15 & TTCCGAACCC & 34,2 \\
\hline 6 & OPZ 05 & TCCCATGCTG & 4,3 \\
\hline 7 & OPG-19 & GTCAGGGCAA & 34,7 \\
\hline 8 & OPC-11 & AAAGCTGCGG & 36,9 \\
\hline 9 & OPA-09 & GGGTAACGCC & 37,4 \\
\hline 10 & OPP-08 & ACATCGCCCA & 37,6 \\
\hline 11 & OPD-03 & GTCGCCGTCA & 40,8 \\
\hline 12 & OPA-02 & TGCCGAGCTG & 40,7 \\
\hline 13 & OPD-20 & ACCCGGTCAC & 39,1 \\
\hline 14 & OPY-09 & AGCAGCGCAC & 42,5 \\
\hline 15 & OPA 05 & AGGGGTCTTG & 32,6 \\
\hline 16 & OPA 11 & CAATCGCCGT & 32,0 \\
\hline 17 & OPG 09 & CTGACGTCAC & 32,0 \\
\hline 18 & PLC 14 & TGCGTGCTTG & 32,0 \\
\hline 19 & PLR 13 & GGACGACAAG & 32,0 \\
\hline \multirow{3}{*}{20} & PLW 04 & CAGAAGCGGA & 32,0 \\
\hline & Chloroplast & & \\
\hline & Primers & & \\
\hline \multirow[t]{2}{*}{1} & $\operatorname{rbcL} 1$ & F: ATG TCA CCA CAA ACA GAA AC & 54,2 \\
\hline & & R: TCG CAT GTA CCT GCA GTA GC & \\
\hline 2 & $\operatorname{rbcL} 2$ & F: TAT GCG TTG GAG AGA CCG TTT C & 57,2 \\
\hline
\end{tabular}




\begin{tabular}{|c|c|c|c|}
\hline \multirow{3}{*}{3} & \multirow{3}{*}{ rbcL 3} & R: TCG CAT GTA CCT GCA GTA GC & \multirow{3}{*}{54,05} \\
\hline & & F: ATG TCA CCA CAA ACA GAA AC & \\
\hline & & R: TCC TTT TAG TAA AAG ATT GGG CCG AG & \\
\hline \multirow[t]{2}{*}{4} & $\operatorname{rbcL} 4$ & F: TAT GCG TTG GAG AGA CCG TTT C & 54,05 \\
\hline & & R: TCC TTT TAG TAA AAG ATT GGG CCG AG & \\
\hline \multirow[t]{2}{*}{5} & matK 1 & F: CAT GCA TTA TGT TAG GTA TCA AGG & 50,05 \\
\hline & & R: CGA AGT ATA TAY TTT ATT CGA TAC A & \\
\hline \multirow[t]{2}{*}{6} & matK 2 & F: CCA TAG TTC CAA TTA TTC CTC TG & 49,65 \\
\hline & & R: CGA AGT ATA TAY TTT ATT CGA TAC A & \\
\hline \multirow[t]{2}{*}{7} & matK 3 & F: CCC CCA TAT ATT TGA TAC CTT CTC & 51,1 \\
\hline & & R: CGA AGT ATA TAY TTY ATT CGA TAC A & \\
\hline \multirow[t]{2}{*}{8} & matK 4 & F: CAT GCA TTA TGT TAG GTA TCA AGG & 54,1 \\
\hline & & R: GCT TGC ATT TTT CAT TGC ACA CG & \\
\hline \multirow[t]{2}{*}{9} & matK 5 & F: CCA TAG TTC CAA TTA TTC CTC TG & 53,7 \\
\hline & & R: GCT TGC ATT TTT CAT TGC ACA CG & \\
\hline \multirow[t]{2}{*}{10} & matK 6 & F: CCC CCA YAT ATT TGA TAC CTT CTC & 55,1 \\
\hline & & R: GCT TGC ATT TTT CAT TGC ACA CG & \\
\hline \multirow[t]{2}{*}{11} & matK 7 & F: CAT GCA TTA TGT TAG GTA TCA AGG & 50,65 \\
\hline & & R: ATT CGA GTA ATT AAA CGT TTT ACA A & \\
\hline \multirow[t]{2}{*}{12} & matK 8 & F: CCA TAG TTC CAA TTA TTC CTC TG & 50,25 \\
\hline & & R: ATT CGA GTA ATT AAA CGT TTT ACA A & \\
\hline \multirow[t]{2}{*}{13} & matK 9 & F: CCC CCA YAT ATT TGA TAC CTT CTC & 51,7 \\
\hline & & R: ATT CGA GTA ATT AAA CGT TTT ACA A & \\
\hline \multirow[t]{2}{*}{14} & matK 10 & F: CAT GCA TTA TGT TAG GTA TCA AGG & 52,1 \\
\hline & & R: CCA GAA ATT GAC AAG GTA ATA TTT & \\
\hline \multirow[t]{2}{*}{15} & matK 11 & $\mathrm{CC}$ & 51,7 \\
\hline & & F: CCA TAG TTC CAA TTA TTC CTC TG & \\
\hline \multirow[t]{5}{*}{16} & matK 12 & R: CCA GAA ATT GAC AAG GTA ATA TTT & 53,15 \\
\hline & & & \\
\hline & & F: CCC CCA TAT ATT TGA TAC CTT CTC & \\
\hline & & R: CCA GAA ATT GAC AAG GTA ATA TTT & \\
\hline & & $\mathrm{CC}$ & \\
\hline
\end{tabular}

\section{Results and Discussion}

Three primers of the evaluated primers, SSR (developed from $P$. indicus), RAPD and chloroplast primers, could amplify DNA samples. Those of SSR primers were pin 2_39, pin2_36, pin2_29, pin2_04, pin1_04, and pin1_01 (Table 2). Each primer amplified two until seven DNA samples from Rote, Lembata, Sika, and Alor. Figure 1 and 2 present the electropherogram of PCR products using six SSR primers. Figure 1 depicts only two of 12 DNA samples could be generated using Pin2-29, sample \#1 and 5, which was from Alor.

Table 2. PCR amplification product information using SSR primers

\begin{tabular}{cccccc}
\hline No & $\begin{array}{c}\text { Primer } \\
\text { name }\end{array}$ & $\begin{array}{c}\text { Number } \\
\text { of } \\
\text { amplified } \\
\text { sample }\end{array}$ & $\begin{array}{c}\text { Annealing } \\
\text { temperature }\end{array}$ & Provenance & Band \\
\hline 1 & Pin2_39 & 6 & 62,6 & Rote,Lembata,Sika,Alor & $\begin{array}{l}\text { Thin and } \\
\text { clear }\end{array}$ \\
\hline
\end{tabular}




\begin{tabular}{|c|c|c|c|c|c|}
\hline 2 & Pin2_36 & 4 & 56,2 & Sika,Alor & $\begin{array}{l}\text { Thick and } \\
\text { clear }\end{array}$ \\
\hline 3 & Pin2_29 & 2 & 52,4 & Rote,Lembata & $\begin{array}{l}\text { Thin and } \\
\text { clear }\end{array}$ \\
\hline 4 & Pin2_04 & 7 & 51,7 & Rote,Lembata,Sika,Alor & $\begin{array}{l}\text { Thick and } \\
\text { clear }\end{array}$ \\
\hline 5 & Pin1_04 & 5 & 58 & Rote,Lembata,Sika,Alor & $\begin{array}{l}\text { Thick and } \\
\text { clear }\end{array}$ \\
\hline 6 & Pin1_01 & 4 & 53,5 & Rote,Lembata,Sika,Alor & $\begin{array}{l}\text { Thin and } \\
\text { clear }\end{array}$ \\
\hline 7 & Pin1_23 & 0 & - & - & Unamplified \\
\hline
\end{tabular}

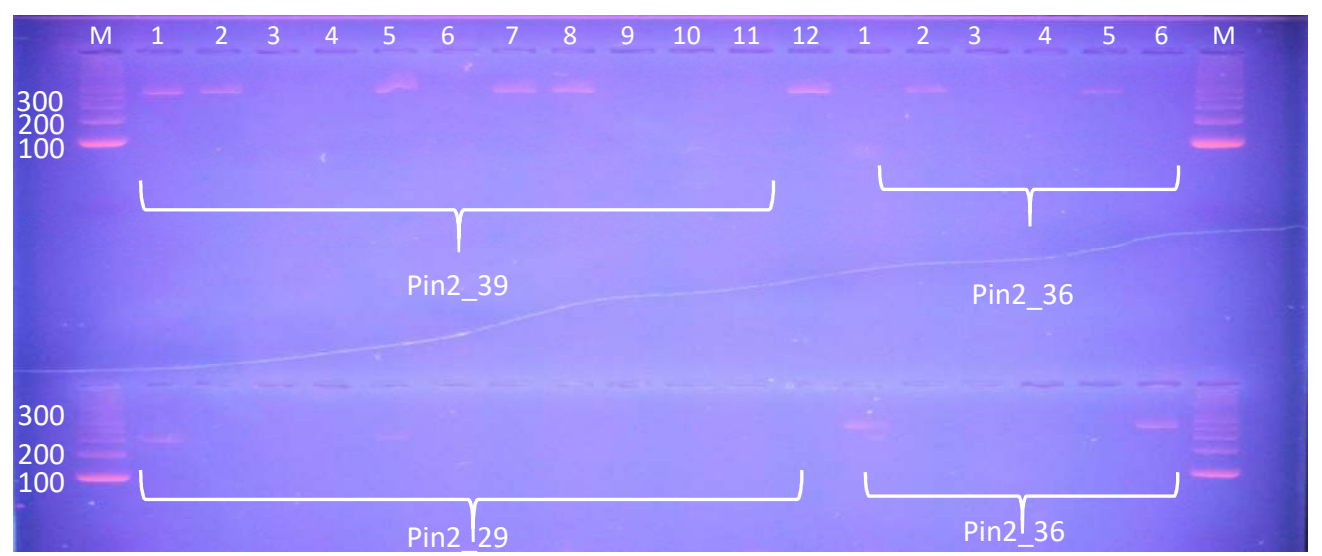

Fig 1. Electropherogram of DNA amplification products of Red wood using SSR primers of P. indicus, Pin2_39, Pin2_36, and Pin2_29. Notes: $\mathrm{M}=100 \mathrm{bp}$ marker, 1-12 = DNA amplification products using Pin2-39 Pin2-29, and Pin2-36 


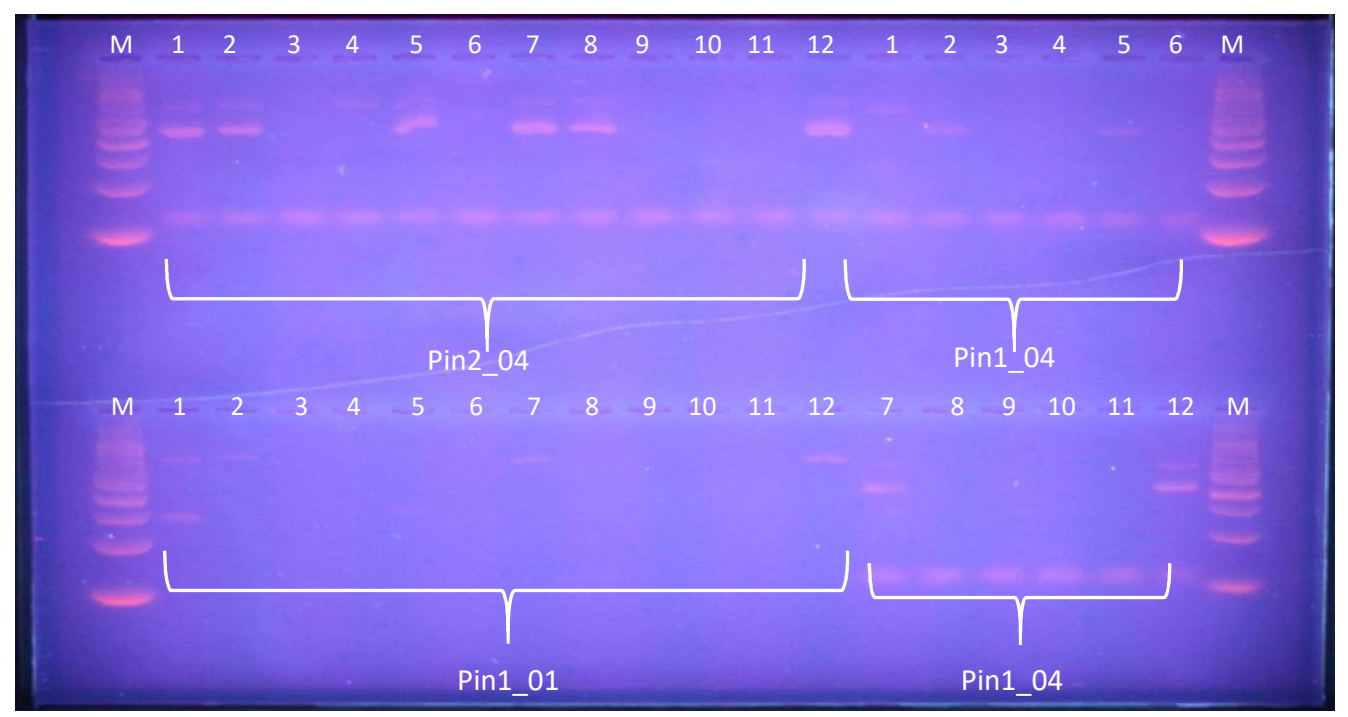

Fig 2. Electropherogram of DNA amplification products of Red wood using SSR primers of $P$. indicus, Pin2_04, Pin1_01, and Pin1_04. Notes: $M=100$ bp marker, $1-12=$ DNA amplification products using Pin2_04, Pin1_01, and Pin1_04.

SSR primers of $P$. indicus that amplified DNA samples were Pin2_39, Pin2_36, Pin2_29, Pin2_04, Pin1_04, and Pin1_01 (Table 2). Each primer was only able to generate one from 12 evaluated samples. As the primers could only amplify one sample, they are eliminated for further analysis on genetic diversity. Genetic diversity analysis requires primers that produce polymorphic bands (many alleles) in order to distinguish the individuals and calculate the parameters of genetic diversity analysis. [11] employed polymorphic primers for measuring parameters of genetic diversity analysis.

Genetic diversity using SSR primer has been widely applied on tree species as it is categorized as a co-dominant primer that able to distinguish between homozygote and heterozygote individuals. This primer is used to analyze the genetic diversity of Anthocephalus macrophyllus [12].

P. alba is in the same family with Red wood, fabaceae. Thus its primers can be used to amplify Red woods DNA. Meanwhile, SSR primers belonged to $P$. indicus were also utilized because of sharing the same Latin name, Pterocarpus indicus, with Red wood. SSR primers of P. indicus generated more DNA than P. albas' due to taxonomic closeness to Red wood. [11] stated that SSR primer screening originated from a species can be employed to its close relatives as they have similar base sequences. However, in this study, none of those evaluated primers could generate DNAs of Red wood (Figure 3).

rbcL 2 generated four DNA samples and had the highest number of successfully amplified samples. Those successfully amplified samples were from Lembata (two samples), Alor and Sika (one sample, respectively). rbcL 1 and matK 1 amplified two samples from Lembata, and rbcL 4, matK 2, and matK 4 amplified one sample from Lembara, respectively (Table 3). Figure 2 depicts the electropherogram of amplified DNA products using rbcL 4. 


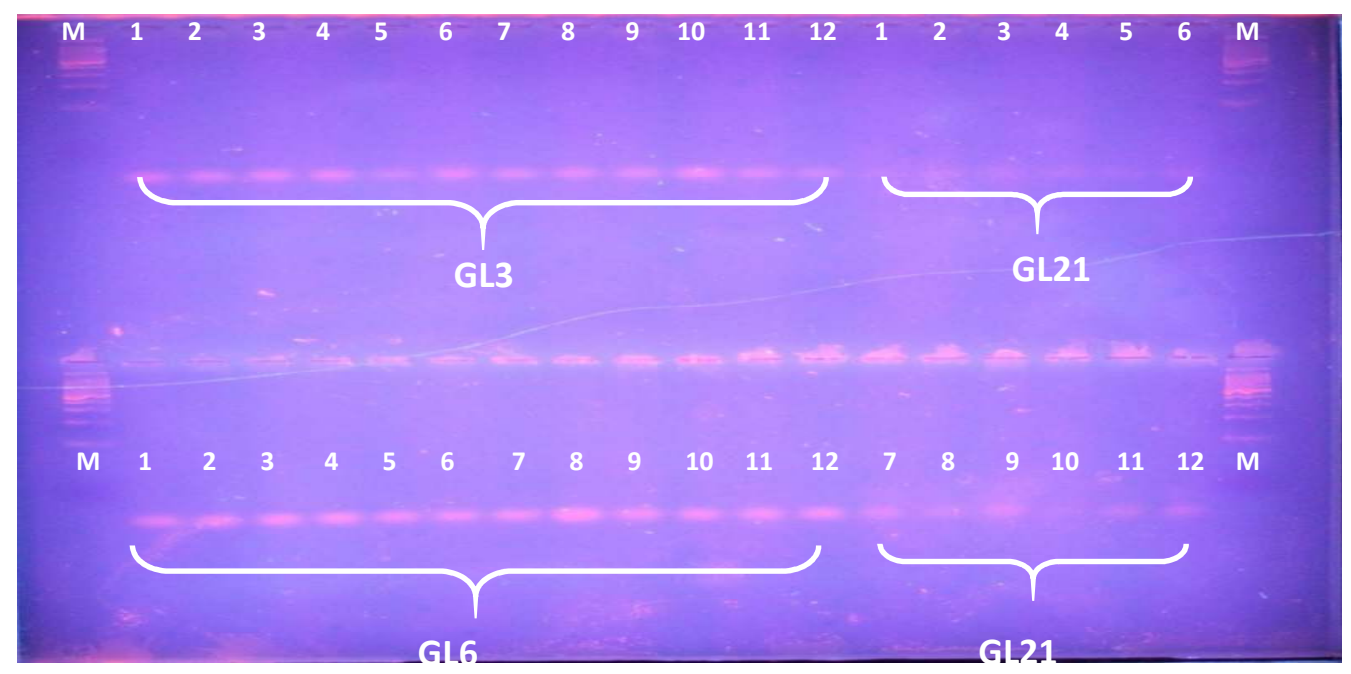

Fig 3. Electropherogram of DNA amplification products of Red wood using SSR primers of $P$. alba, GL3, GL6, and GL21. Notes: $\mathrm{M}=100$ bp marker, 1-12 = DNA amplification products

Table 3. PCR amplification product information using chloroplast primer

\begin{tabular}{ccccc}
\hline No & Primer name & $\begin{array}{c}\text { Number of } \\
\text { amplified sample }\end{array}$ & $\begin{array}{c}\text { Annealing } \\
\text { temperature }\end{array}$ & Note \\
\hline 1 & rbcL 1 & 2 & 52,4 & Thick and clear \\
2 & rbcL 2 & 4 & 55,5 & Thick and clear \\
3 & rbcL 3 & 0 & - & Unamplified/No product \\
4 & rbcL 4 & 1 & 52,4 & Thick and clear \\
5 & matK 1 & 2 & 48,4 & Thin and clear \\
6 & matK 2 & 1 & 48,0 & Thick and clear \\
7 & matK 3 & 0 & - & Unamplified/No product \\
8 & matK 4 & 1 & 52,4 & Thick and clear \\
9 & matK 5 & 0 & - & Unamplified/No product \\
10 & matK 6 & 0 & - & Unamplified/No product \\
11 & matK 7 & 0 & - & Unamplified/No product \\
12 & matK 8 & 0 & - & Unamplified/No product \\
13 & matK 9 & 0 & - & Unamplified/No product \\
14 & matK 10 & 0 & - & Unamplified/No product \\
15 & matK 1 & 0 & - & Unamplified/No product \\
16 & matK 12 & 0 & &
\end{tabular}




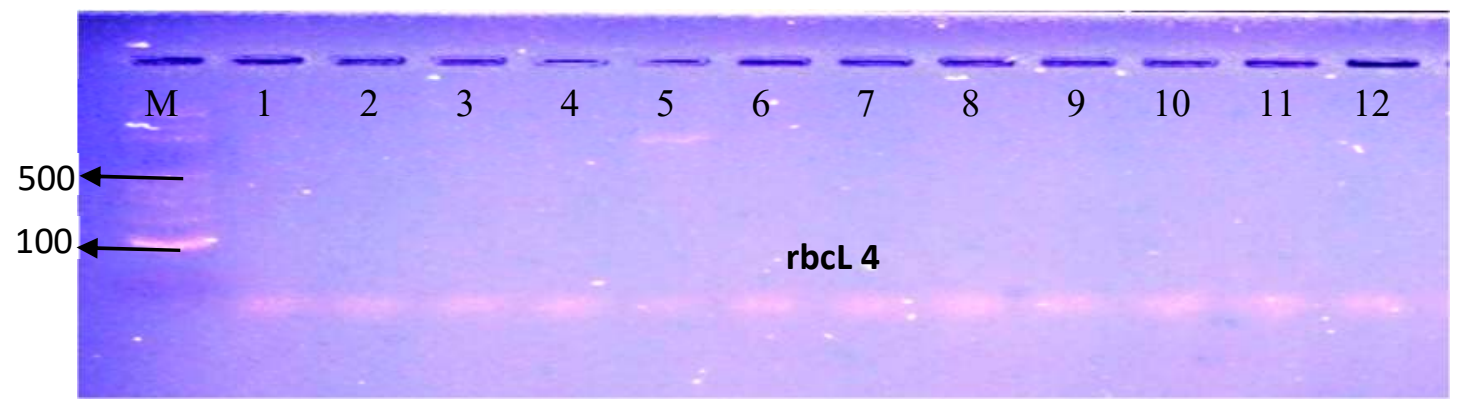

Fig 3. Electropherogram of DNA amplification products of Red wood using chloroplast primer, rbcL4. Notes : $\mathrm{M}=100 \mathrm{bp}$ marker, 1-12 = DNA amplification products

In general, rbcL ( 3 of 4 primers) primers amplified more samples than matK ( 3 of 12 primers). This result was assumed as rbcL primers have more general sequences, yet, lower accuracy in distinguishing individuals between species than matK [13] and [14].

Screening primer using 20 RAPD primers showed 16 primers could amplify the DNA samples. Allele number of amplified samples was ranged one to nine alleles. That of the highest was using OPA 02 (nine alleles), OPD 03 and OPAC 12 were five alleles, and OPA 15, OPA 09, OPY 09, and OPG 09 were three alleles, respectively. Moreover, OPAE 11, OPC 11, OPA 11, PLR 13, and PLW 04 were two alleles, OPQ 07 and PLC 14 were 1 allele (the lowest), and OPAA 20, OPA 05, OPG 19, and OPD 20 were none, respectively. A total number of the band was 49 polymorphic bands, and the highest was obtained by OPA 02 (nine alleles). The monomorphic bands were observed using OPQ 07 and PLC 14. Polymorphism was also detected on the 16 evaluated primers. Polymorphism is the existence of locus or amplicon (present band) with different sizes on one primer. The presence of the band can be polymorphic and monomorphic primer (the existence of locus with the same size on the analyzed samples) [15].

As many as 20 RAPD primers screened by [16] using Mahogany DNA and [17] using DNA Gigantochloa atter to obtain polymorphic primers. Those studies only received four polymorphic primers that could be used in genetic diversity analysis. Criteria of proper primers for genetic diversity analysis are good reproducibility, producing polymorphic, bright, clear, stable as well as easy to score bands [18].

This study is in similar to the previous study by [16] who found two RAPD primers which polymorphically amplified DNA $S$. mahogany, OPQ 07 and OPAE 11, but contrast in OPG 19 and OPA 05 primers. In this study, none of both primers could amplify the DNA. Meanwhile, [17] selected OPA 15, OPZ 05, OPA 05, and OPK 20 to generate polymorphically $G$. atter DNA.

Primer selection on RAPD primers influences polymorphism of the produced bands as each primer has specific annealing site. As consequent of the specific annealing site, every primer generates different polymorphic bands both size and number of DNA bands. Polymorphism refers to the visualization of amplification based on different observed DNA fragments and score in order to determine whether the variation is presented by observing the sequence differences. 
Table 4. PCR amplification product information using RAPD primer

\begin{tabular}{|c|c|c|c|c|c|c|}
\hline No & $\begin{array}{l}\text { Locus } \\
\text { Name }\end{array}$ & $\begin{array}{c}\text { Number of } \\
\text { amplified } \\
\text { sample }\end{array}$ & $\begin{array}{c}\text { Annealing } \\
\text { Temperature } \\
\left({ }^{\circ} \mathrm{C}\right)\end{array}$ & Provenance & Note & $\begin{array}{c}\text { Numbe } \\
\text { r of } \\
\text { allele }\end{array}$ \\
\hline 1 & OPQ 07 & 2 & 40,2 & Rote & Clear & 1 \\
\hline 2 & OPA 15 & 4 & 37,1 & $\underset{\mathrm{e}}{\text { Sika,Lembata,Rot }}$ & Clear & 3 \\
\hline 3 & OPZ 05 & 4 & 37,1 & $\begin{array}{c}\text { Lembata,Rote,Sik } \\
\text { a }\end{array}$ & Clear & 4 \\
\hline 4 & OPD 03 & 3 & 42,5 & Lembata,Rote & Clear & 5 \\
\hline 5 & OPA 02 & 4 & 46,9 & $\underset{\mathrm{e}}{\text { Sika,Lembata,Rot }}$ & Thin and clear & 9 \\
\hline 6 & OPP 08 & 3 & 33,8 & Lembata,Rote & Thin and clear & 4 \\
\hline 7 & OPA 09 & 4 & 34,6 & $\begin{array}{l}\text { Sika,Timur } \\
\text { Tengah } \\
\text { Selatan,Rote }\end{array}$ & Clear & 3 \\
\hline 8 & OPAE 11 & 2 & 42,1 & Rote & Thin and clear & 2 \\
\hline 9 & $\begin{array}{l}\text { OPAA } \\
20\end{array}$ & 0 & - & - & $\begin{array}{l}\text { Unamplified/No } \\
\text { product }\end{array}$ & 0 \\
\hline 10 & OPA 05 & 0 & - & - & $\begin{array}{l}\text { Unamplified/No } \\
\text { product }\end{array}$ & 0 \\
\hline 11 & OPG 19 & 0 & - & - & $\begin{array}{c}\text { Unamplified/No } \\
\text { product }\end{array}$ & 0 \\
\hline 12 & OPC 11 & 2 & 39,7 & Rote & Thin and clear & 2 \\
\hline 13 & $\begin{array}{l}\text { OPAC } \\
12\end{array}$ & 5 & 33,6 & Lembata,Rote & Thin and clear & 5 \\
\hline 14 & OPD 20 & 0 & - & - & $\begin{array}{c}\text { Unamplified/No } \\
\text { product }\end{array}$ & 0 \\
\hline 15 & OPY 09 & 3 & 43,6 & Lembata,Rote & Clear & 3 \\
\hline 16 & OPA 11 & 3 & 34,8 & $\begin{array}{c}\text { Sika,Lembata,Rot } \\
\mathrm{e}\end{array}$ & Unclear/Smear & 2 \\
\hline 17 & OPG 09 & 2 & 29,2 & Lembata,Rote & Unclear/Smear & 3 \\
\hline 18 & PLC 14 & 1 & 27,0 & Rote & Thin and clear & 1 \\
\hline 19 & PLR 13 & 4 & 32,0 & $\begin{array}{c}\text { Sika,Lembata,Rot } \\
\mathrm{e}\end{array}$ & Clear & 2 \\
\hline 20 & PLW 04 & 2 & 33,7 & Rote & Thin and clear & 2 \\
\hline
\end{tabular}




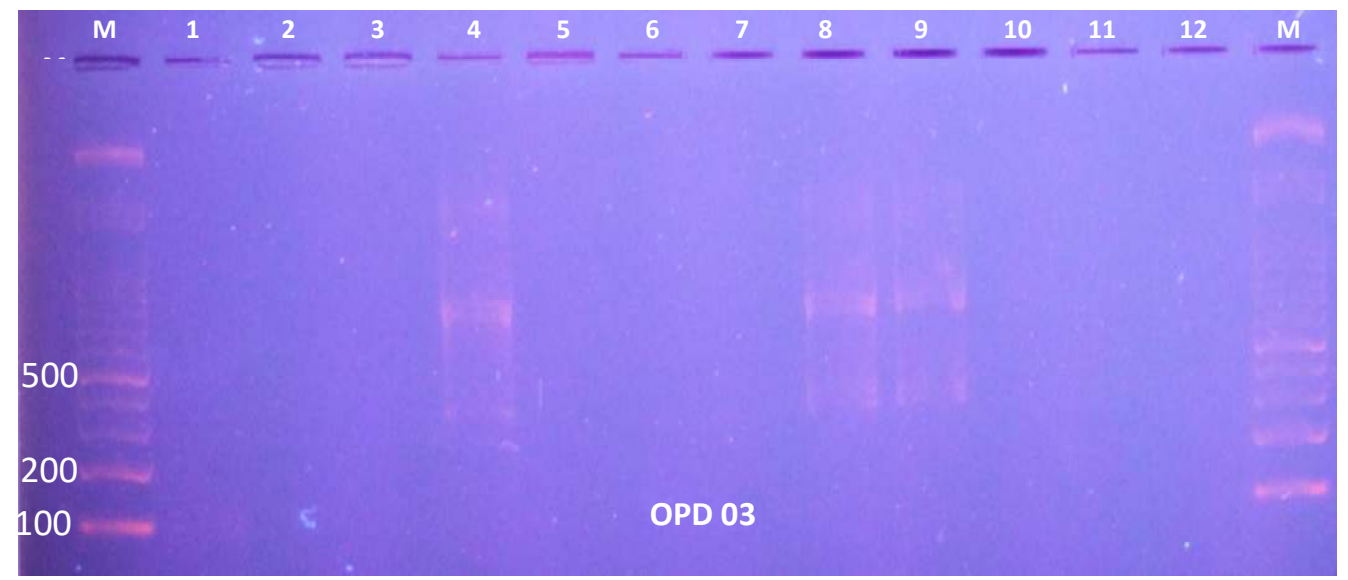

Fig 4. Electropherogram of DNA amplification products of Red wood using RAPD primers, OPD-03. Notes : $\mathrm{M}=100$ bp marker, 1-12 = DNA amplification products

RAPD is still used to analyze genetic diversity because of its ability to amplify various species, like Pinus merkusii [19] in Educational Forest Hasanuddin University, onion (Allium cepa L) [20], Dioscorea sp [21], and Indonesian Edible Canna (Canna indica L.) [22]. The comparison co-dominant and dominant primers have been performed in molecular research, in genetic diversity using RAPD and SSR of Ustilago hordei [23], and Zingiber officinale [24]. SSR and SNAP marker to calculate the xenia effect in Kopyor coconut [25], and to analysis mating system in Ebony, Jabon Merah and Kopyor coconut [26,27,28].

\section{Conclusion}

The results concluded that there were sixteen out of twenty RAPD primers showed good amplification products and polymorphisms. Four of 6 SSR primers developed from $P$. Indicus generated DNA samples, while that of originated from $P$. alba could not amplify any DNA. rbcL and matK successfully amplified the evaluated DNA for Red Wood DNA amplification along with specific PCR temperature in each primer.

\section{Acknowledgment}

The author thanks The $2^{\text {nd }}$ Seed/Seedling Forest Office (Sulawesi BPTH) for providing plant materials, Andi Fahriadi Amir, Gunawan, Yuni Fitri Cahyaningsih dan Mirza Arsiaty Arsyad for participating in this research activities.

\section{References}

[1] Pongtuluran, I., Restu M., and Gusmiaty: Primary Selection for the Genetic Diversity of Bitti (Vitex coffasus). Jurnal Perennial. Vol. 8 (1), pp. 25-29 (2012)

[2] Weeden, N. F. G. M., M. Timmerman, B. E. Hemmat, M. A. Kneen, and Lodhi: Inheritance and Reliability of RAPD Markers. In Applications of RAPD Technology to 
Plant Bredding. Symposium Proceedings. Crop Science Society of America, Madison. Pp. 12-17 (1992)

[3] Cheng, K. T., H. C. Chang, C. H. Su, and F. L. Hsu: Identification of dried rhizomes of Coptis species using random amplified polymorphic DNA. Botanical Bulletin of Academia Sinica. Vol. 38, pp. 241-244 (1997)

[4] Tani, N., Y. Tsumura, T. Kado, Y. Taguchi, S. L. Lee, N. Muhammad, S. Numata, S. Nishimura, A. Konuma, and T. Okuda: Paternity analysisbased inference of pollen dispersal patterns, male fecundity variation, and influence of flowering tree density and general flowering magnitude in two dipterocarp species. Annals of Botany, Vol.104, pp. 1421-1434 (2009)

[5] Karakousis, A., A. R. Barr, K. J. Chalmers, G. A. Ablett, T. A. Holton, R. J. Henry, P. Lim, and P. Langridge: Potential of SSR markers for plant breeding and variety identification in Australian barley germplasm. Australian Journal of Agricultural Research Vol. 54 (12), pp. 1197-1210 (2003)

[6] Li, X., Y. Yang., R. J. Henry, M. Rossetto, Y. Wang, and S. Chen: Plant DNA barcoding: from gene to genome. Biol. Rev. Doi: 10. 1111/brv. 12104 (2014)

[7] Sulistyawati, P., dan Widyatmoko, A. Y. P. B. C: Keragaman Genetik Populasi Kayu Merah (Pterocarpus indicus Willd.) Menggunakan Penanda Random Amplified Polymorphism DNA. Yogyakarta (2017)

[8] Abubakar, M. H.: Seleksi Primer Untuk Analisis Keragaman Genetik Uru (Elmerillia tsiampacca). Skripsi Sarjana Fakultas Kehutanan Universutas Hasanuddin (2012)

[9] Mangiwa, S. T.: Seleksi Primer untuk Analisis Keragaman Genetik Tanaman Mahoni (Swietenia mahagoni). Skripsi Sarjana Fakultas Kehutanan Kehutanan Universitas Hasanuddin (2012)

[10] Nurutami, K.: Seleksi Primer Mikrosatelit Mahoni (Swietenia macrophylla). Skripsi Sarjana Fakultas Kehutanan Universutas Hasanuddin (2018)

[11] Nurtjahjaningsih, I. L. G., A. Y. P. B. C. Widyatmoko, P. Sulistyawati dan Rimbawanto, A.: Karakteristik dan Aplikasi Penanda Mikrosatelit pada Beberapa Spesies Eucalyptus. Balai Besar Penelitian Bioteknologi dan Pemuliaan Tanaman Hutan. Yogyakarta. Vol.7, pp. 107-108 (2013)

[12] Larekeng SH.,Restu M., Gusmiaty, Syamsuddin M., Budirman B.: Moderate Level of Genetic diversity in Anthocephalus macrophyllus Roxb, an endemic tree of Sulawesi and Its Implication in conservation. Int. J. Agr. Syst. Vol (6), pp. 74-81 (2018)

[13] Wattoo, J. I., Saleem, M. Z., Shahzad, M. S., Arif, A., Hameed, A., and Saleem, M. A.: DNA Barcoding: Amplification and sequence analysis of rbcl and matK genome regions in three divergent plant species. [Short Communication], Advancements in Life Sciences. Vol 4(1), pp. 1-5 (2016)

[14] Gonzalez, M. A., Baraloto, C., Engel, J., Scott A. M., Pascal P., Bernard R., Aure' lien R., Christophe T., Je'ro^me C.: Identification of Amazonian Trees with DNA Barcodes. Vol. 4 (10), pp. 1-7 (2009)

[15] Berdakci F.: Random amplified polymorphic DNA (RAPD) markers [review]. Turk J Biol. Vol. 25, pp. 185-196 (2001)

[16] Iswanto.: Analisis Keragaman Genetik Jenis Mahoni (Swietenia mahagoni (L) Jacq) pada Berbagai Sumber Benih di Sulawesi Selatan. Skripsi Sarjana Fakultas Kehutanan Universitas Hasanuddin (2016)

[17] Larekeng, S.H., Restu M., Mis;al, Oktavina J, Cahyaningsih YF.b.: Penggunaan Penanda RAPD Untuk Mengevaluasi Keragaman Genetik Bambu Parring (Gigantochloa 
atter) di Kabupaten Maros Sulawesi Selatan. Prosiding Seminar Nasional Silvikultur V Lambung Mangkurat University Press. pp. 404-413 (2018)

[18] Cannon, J., Robert A.S., Lynn C., Wendy H.Y., Joanne C.S.: Optimization of PCR primers to detect phylogenetically diverse nrfA genes associated with nitrite ammonification. Journal of Microbiological Methods Vol. 160. Pp. 49-59 (2019).

[19] Gusmiaty, Restu M, Asriyanni, Siti H.L.: Polimorfisme Penanda RAPD untuk Analisis Keragaman Genetik Pinus merkusii di Hutan Pendidikan Unhas. Jurnal Natur Indonesia Vol. 12, pp. 47-53 (2016)

[20] Sudha, G.S., P. Ramesh, A.Chandra S., T.Sail K., Bramhachari, K.Riazunnisa.: Genetic diversity analysis of selected Onion (Allium cepa L.) germplasm using specific RAPD and ISSR polymorphism markers. Biocatalysis and Agricultural Biotechnology. Vol. 17, pp. 110-118 (2019)

[21] Purnomo, Daryono BS, Rugayah, Sumardi I, Shiwachi H.: Genetic variability and classification of Indonesian Yams (Dioscorea spp.) based on RAPD analysis. SABRAO J. Breed. Genet. Vol. 48, pp. 377-390 (2016)

[22] Sari N, Suryadiantina, B.S. Daryono and Purnomo.: Variability And Intraspecific Classification Of Indonesian Edible Canna (Canna indica L.) Based On RAPD Marker Analysis. SABRAO Journal of Breeding and Genetics. Vol. 50, pp. 156-167 (2018)

[23] Zhou,Y., Gui-Mie C., Jia-Jia L., Ming-qi Z., Yang W., Bai-li F.: Genetic diversity of Ustilago hordei in Tibetan areas as revealed by RAPD and SSR. Journal of Integrative Agriculture. Vol.15 (10), pp. 2299-2308 (2016)

[24] Baruah, J., Sudin K.P., Twahira B, Neelav S, Manabi P, Mohan L.: Molecular diversity assessed amongst high dry rhizome recovery Ginger germplasm (Zingiber officinale Roscoe) from NE-India using RAPD and ISSR markers. Industrial Crops and Products. Vol. 129, pp. 463-471 (2019)

[25] Maskromo I, Siti H.L., Hengky N and Sudarsono S.: Xenia negatively affecting kopyor nut yield in Kalianda Tall kopyor and Pati Dwarf kopyor coconuts. Emir. J. Food Agric Vol. 28, pp. 644-52 (2016)

[26] Restu, M., Gusmiaty, dan Siti H.L.,: High Outcrossing Rate And Pollen Dispersal Distance of Diospyros celebica Bakh. (Ebenaceae), an Endemic Tree Species In Sulawesi Island, Indonesia. Biotropia, Vol. 24, pp. 173 - 181 (2017)

[27] Larekeng SH, M Restu, A Arif, Y F Cahyaningsih, and J Mukti.: A genetic approach to study mating system on Jabon Merah (Anthocephalus macrophyllus Roxb.) from three different provenances in South Sulawesi. IOP Conf. Ser.: Earth Environ. Sci.pp. 1-9. (2019)

[28] Larekeng SH, Purwito A, Mattjik NA and Sudarsono: Microsatellite and SNAP markers used for evaluating pollen dispersal on Pati tall coconuts and Xenia effect on the production of 'Kopyor' fruits IOP Conf.Ser.: Earth Environ.Sci. Vol. 157. Pp. 012-042 (2018). 